\title{
EVALUASI SETTING RELE JARAK (DISTANCE RELAY) PADA SALURAN UDARA TEGANGAN TINGGI (SUTT) 150 kV ANTARA GARDU INDUK SIDERA-GARDU INDUK TIPO
}

\author{
Martho Pamula ${ }^{\text {1), }}$, Sangbua Dinsol Pirade ${ }^{2)}$, Yulius Salu Pirade ${ }^{3)}$,Nurhani Amin ${ }^{4)}$ \\ ${ }^{1,2)}$ Mahasiswa Teknik Elektro Universitas Tadulako, \\ ${ }^{3,4}$ Dosen Teknik Elektro Universitas Tadulako \\ Program Studi S1 Teknik Elektro, Fakultas Teknik, Universitas Tadulako \\ E-mail : ys67.pirade@gmail.com, nhanie.lieben@ymail.com
}

\begin{abstract}
Overhead line high voltage (SUTT) or commonly called a transmission network or transmission line has very important role in the process of distribution of electrical from power plants to load centers continuously. However, overhead line is one component in the system which is often fault. To avoid damages and greater losses, it has used the distance which is as the primary protection in securing the transmission network or transmission line. In this research, it discussed about one phase-neutral short circuit that happens on line transmission connected to Sidera-Tipo substation by calculating the current fault and operating time of distance relay using the software of ETAP (electric transientandanalysis program) 12.6.0. The results of this research showed that the largest current fault occur on the type of one phaseneutral short circuit distance of $20 \%$ is $2069,50 \mathrm{~A}$, and the other one of the largest current fault occur on the type one phase-neutral short circuit distance of $100 \%$ is $1753,98 \mathrm{~A}$, and esultdetermining setting of distance relay for zone-1 value zsetting-1 is 17,566 $\Omega$.
\end{abstract}

Keywords: One Phase-Neutral Short Circuit, Distance Relay, Protection, Transmission Line

\section{PENDAHULUAN}

Hubung singkat merupakan salah satu jenis gangguan yang sering terjadi pada suatu sistem tenaga listrik, baik itu arus hubung singkat antara kawat phasa ke tanah maupun arus hubung singkat antara kawat yang berbeda phasanya. Saat gangguan terjadi, arus yang mengalir pada saluran transmisi yang menuju pusat gangguan sangat besar, sehingga akan mempengaruhi kestabilan dari keseluruhan sistem, untuk itu peralatan proteksi diharapkan mampu mendeteksi dan dapat memisahkan daerah yang terganggu dan daerah yang tidak terganggu, sehingga konsumen dapat mendapatkan energi listrik secara kontinyu pada daerah yang tidak terganggu. Dalam sistem proteksi saluran transmisi, rele yang digunakan untuk mengatasi gangguan adalah rele jarak, rele arus hubung singkat, rele arus lebih, rele diferensial, rele hubung tanah, dan kawattanah. Saat ini di kota palu masih kekurangan pasokan listrik, ini terlihat dengan masih adanya pemadaman listrik. Sistem proteksi tenaga listrik merupakan sistem pengamanan pada peralatan-peralatan yang terpasang pada sistem tenaga listrik, seperti generator, busbar, transformator, saluran udara tegangan tinggi, saluran kabel bawah tanah, dan lain sebagainya terhadap kondisi abnormal operasi sistem tenaga listrik tersebut. Fungsi sistem proteksi tenaga listrik yaitu :

1. Memutuskan dan memisahkan hubungan sistem (tripping) pada jaringan transmisi yang terganggu dan tidak terganggu dengan cepat, guna menjaga stabilitas, kontinuitas, pelayanan kerja dari sistem.

2. Mencegah kerusakan peralatan-peralatan pada sistem tenaga listrik akibat terjadinya gangguan atau kondisi operasi sistem yang tidak normal.

3. Mempersempit daerah yang tidak terganggu sehingga gangguan tidak melebar pada sistem yang lebih luas.

4. Mengamankan manusia dari bahaya yang ditimbulkan oleh tenaga listrik akibat gangguan.

5. Mengisolasi area atau sistem yang terganggu secepat mungkin dan sekecil mungkin. Semakin cepat reaksi perangkat proteksi yang digunakan maka akan semakin sedikitlah pengaruh gangguan kepada kemungkinan kerusakan alat.

6. Memaksimalkan ketersedian listrik untuk konsumen.

Untuk membatasi luasnya sistem tenaga listrik yang terputus saat terjadi gangguan, maka sistem proteksi dibagi dalam zona-zona 
gangguan. Sistem proteksi yang andal adalah rele yang digunakan harus bekerja sesuai dengan zona settingnya dan mampu mengamankan zonanya masing-masing . Sistem proteksi ditinjau dari jenis dan dalam penggunaannya harus memiliki syaratsyarat yang penting dalam pengoperasiannya sehingga dapat bekerja sesuai dengan fungsinya secara maksimal.

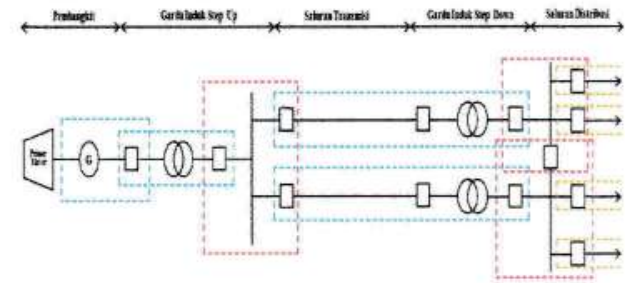

Gambar 1. Zona Proteksi.

Rele jarak (distance relay) merupakan salah satu jenis rele proteksi yang digunakan sebagai pengaman pada saluran transmisi karena kemampuannya dalam menghilangkan gangguan (fault clearing) dengan cepat dan penyetelannya yang relative mudah. Pada prinsipnya rele jarak (distance relay) adalah mengukur nilai arus dan nilai tegangan pada suatu titik tertentu sehingga diperoleh nilai impedansinya, kemudian membandingkannya dengan nilai setting impedansi tertentu dari rele jarak (distance relay) tersebut untuk menentukan apakah rele bekerja atau tidak. Pada SUTT terganggu, maka rele jarak (distance relay) akan melihat turunnya impedansi dari SUTT, kemudian rele jarak (distance relay) pun akan bekerja.[2]

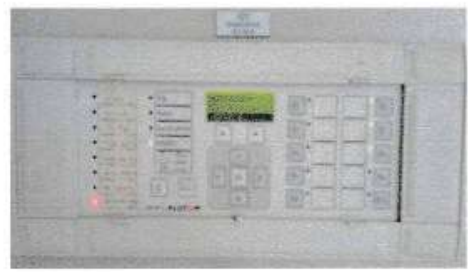

Gambar 2. Rele Jarak (Distance Relay). Sumber : Gardu Induk Sidera.

Rele jarak (distance relay) akan bekerja dengan cara membandingkan impedansi gangguan yang terukur dengan setting impedansi pada rele jarak (distance relay), dengan ketentuan :

1. Jika nilai impedansi gangguan lebih kecil dari pada setting impedansi rele jarak (distance relay), maka rele jarak (distance relay) akan bekerja.

2. Jika nilai impedansi gangguan lebih besar atau sama dengan setting impedansi rele jarak (distance relay), maka rele jarak (distance relay) tidak akan bekerja.

Contoh sederhana sistem proteksi untuk jaringan seperti ditunjukan pada gambar 3 dibawah ini dimana PMT berfungsi untuk memisahkan / menghubungkan satu bagian jaringan dengan bagian yang lain, baik jaringan dalam keadaan normal maupun dalam keadaan terganggu. Bagian-bagian jaringan tersebut dapat terdiri dari satu PMT atau lebih. Dalam usaha meningkatkan keandalan penyediaan energi listrik, kebutuhan sistem proteksi terdiri dari peralatan CT, PT, Rele Proteksi, PMT, Catu daya. Disamping itu diperlukan juga peralatan pendukung untuk kemudahan operasi dan evaluasi terhadap gangguan seperti sistem recorder, sistem scada dan lain-lain.[6]

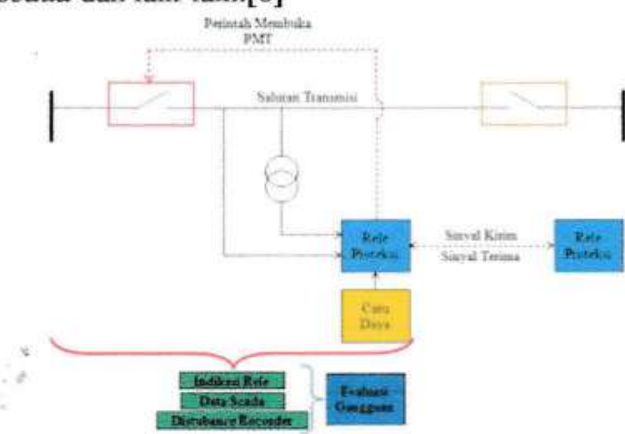

Gambar 3. Blok Diagram Rele Jarak (Distance Relay).

Sumber : Materi Pusat Pendidikan Dan Pelatihan PT. PLN (Persero).

Tingkat-tingkat waktu kerja diantara beberapa rele (time grading) diperlukan agar rele jarak dapat memberikan backup protection. Time grading dapat dicapai dengan metode distance-time (gambar 4), dimana jika semakin dekat jarak gangguan atau hubung singkat dengan jarak rele maka waktu kerjanya semakin cepat atau bahkan tidak ada perlambatan waktu, sebaliknya jika semakin jauh titik gangguan dengan rele maka waktu kerjanya semakin lama. Metode definite-distance, dimana sepanjang jarak jangkauan proteksi, waktu kerja rele tetap dan dari jarak jangkau yang satu menyambung ke jarak jangkau zona, kemudian naik secara bertingkat. (gambar 5).[2]

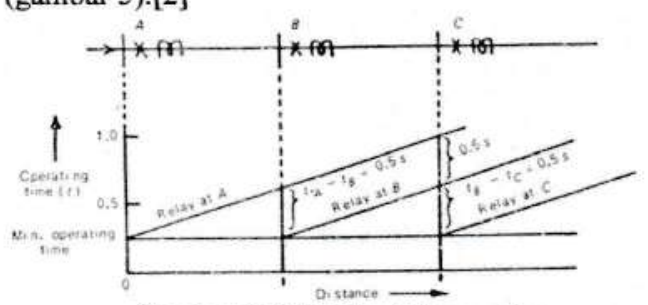

Gambar 4. Metode distance-time. 


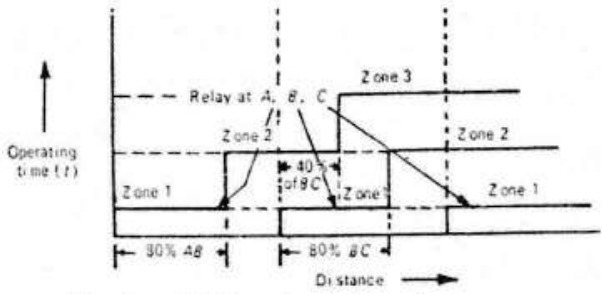

Gambar 5. Metode defenitif-time.

Hubung singkat adalah terjadinya hubungan penghantar bertegangan atau penghantar tidak bertegangan secara langsung melalui media (resistor/beban) yang tidak semestinya, sehingga terjadi aliran arus yang tidak normal (sangat besar). Hubung singkat merupakan salah satu jenis gangguan yang sering terjadi pada suatu sistem tenaga listrik, baik itu hubung singkat antara kawat phasa ketanah maupun hubung singkat antara kawat yang berbeda phasanya. Arus hubung singkat yang begitu besar sangat membahayakan peralatan, sehingga untuk mengamankan peralatan dari kerusakan yang di timbulkan akibat dari arus hubung singkat, maka hubungan kelistrikan pada daerah yang terganggu perlu diputuskan dengan peralatan pemutus tenaga (PMT) atau circuit breaker (CB).[7]
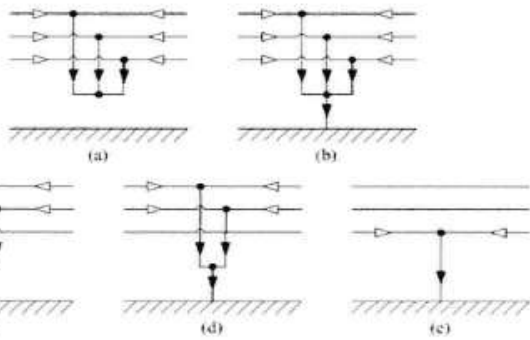

(c)
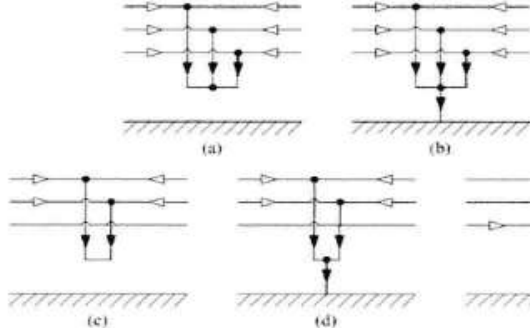

(d)

Gambar 6. Gangguan Hubung Singkat (a) HS. 3 Phasa, (b) HS. 3 Phasa-N, (c) HS. 2 Phasa, (d) HS. 2 Phasa-N, (e) HS. 1 Phasa-N.

Ada beberapa macam gangguan, diantaranya yaitu :

a. Gangguan Berdasarkan Lamanya Gangguan

1. Gangguan Permanen

Gangguan yang bersifat permanen dapat disebabkan oleh kerusakan peralatan sehingga gangguan tersebut baru hilang setelah kerusakan tersebut diperbaiki atau karena ada sesuatu yang mengganggu secara permanen. Contoh gangguan tersebut adalah gangguan hubung singkat, belitan trafo, tembus isolasi dan adanya kawat yang putus.

2. Gangguan Temporer

Merupakan gangguan yang terjadi dalam waktu singkat saja dimana kemudian sistem kembali dalam keadaan normal. b. Gangguan Berdasarkan Analisa Hubung Singkat Adalah :

1. Simetri atau seimbang, gangguannya terdiri dari :

a) Tiga phasa (3ø)

b) Tiga phasa ketanah $(3 \otimes-\mathrm{N})$

2. Tidak simetri atau tak seimbang, gangguannya terdiri dari :

a) Dua phasa (2Q) tanpa tanah

b) Dua phasa ketanah $(2 \otimes-\mathrm{N})$

c) Satu phasa ketanah $(1 \propto-\mathrm{N})$

\section{METODE PENELITIAN}

Sebelum menghitung arus hubung singkat pada sebuah sistem tenaga listrik, perlu diketahui daya $(P)$, arus yang mengalir pada saluran transmisi (I), impedansi saluran dengan panjang sebenarnya $(Z)$, tegangan sisi primer $\left(V_{p}\right)$ dan tegangan sisi sekunder $\left(V_{s}\right)$. Persamaan yang dapat digunakan untuk menghitung nilai-nilai tersebut adalah sebagai berikut :

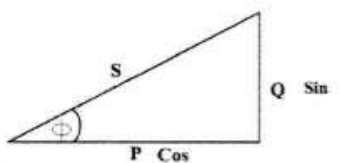

Gambar 7. Segitiga Daya.

$$
\begin{aligned}
& P=S \times \cos \phi . \\
& I_{N}=\frac{P}{\sqrt{3} \times V \times \cos \phi} \\
& Z=\frac{(R+j X) \times l}{\text { Nilai Dasar }}
\end{aligned}
$$

Perhitungan arus hubung singkat pada sebuah sistem tenaga listrik adalah sebagai berikut :

a. Menghitung besar impedansi sumb $\left(Z_{s}\right)$.

$$
Z_{\text {sumber }}=\frac{\text { tegangan dasar }{ }^{2}(\mathrm{kV})^{2}}{\text { daya dasar }(M V A)}
$$

b. Menghitung impedansi trafo tenaga $\left(Z_{T}\right)$. Impedansi urutan positif-negatif $\left(\mathrm{X}_{\mathrm{T} 1}=\mathrm{X}_{\mathrm{T} 2}\right)$

$$
\begin{gathered}
Z_{T}=\frac{\text { tegangan dasar }{ }^{2}(\mathrm{kV})^{2}}{\text { daya dasar }(M V A)} \times \mathrm{X}_{\mathrm{t} \%} \text { (reaktansi trafo).(5) } \\
\text { Impedansi urutan nol }\left(\mathrm{X}_{\mathrm{T} 0}\right)
\end{gathered}
$$

Impedansi urutan nol ini didapat dengan memperhatikan data trafo tenaga itu sendiri yaitu dengan melihat kapasitas belitan delta yang ada dalam trafo itu:

1. Untuk trafo tenaga dengan hubungan belitan $\Delta / Y$ dimana kapasitas belitan deta sama besar dengan kapasitas belitan $\mathrm{Y}$, maka:

$$
\mathrm{Z}_{\mathrm{T} 0}=\mathrm{Z}_{\mathrm{T} 1}
$$


2. Untuk trafo tenaga dengan belitan Yyd dimana kapasitas belitan delta (d) biasanya sepertiga dari kapasitas belitan Y (belitan yang dipakai untuk menyalurkan daya, sedangkan belitan delta tetap ada di dalam tetapi tidak dikeluarkan kecuali satu terminal delta untuk ditanahkan), maka:

$$
\mathrm{Z}_{\mathrm{T} 0}=3 \mathrm{X}_{\mathrm{T} 1}
$$

3. Untuk trafo tenaga dengan hubungan Yy dan tidak mempunyai belitan delta di dalamnya, maka besarnya $X_{\mathrm{T} 0}$ berkisar antara $9 \mathrm{~s} / \mathrm{d} 14$ $\mathrm{X}_{\mathrm{T} 1}$.

$$
\mathrm{Z}_{\mathrm{T} 0}=10 \mathrm{Z}_{\mathrm{T} 1}
$$

c. Menghitung impedansi saluran transmisi.

Impedansi saluran transmisi dihitung tergantung dari besarnya impedansi perkilometer saluran transmisi yang digunakan, dimana besar nilainya ditentukan dari konfigurasi tiang yang digunakan untuk jaringan saluran udara tegangan tinggi (SUTT) atau jenis konduktor untuk jaringan transmisi. Berikut persamaan yang digunakan :

$Z=\frac{(R+j X) \Omega}{\mathrm{km}} \times$ panjang saluran sebenarnya $(l)$

d. Mengitung impedansi ekivalen jaringan.

Perhitungan $\mathrm{Z}_{1}$ eq dan $\mathrm{Z}_{2}$ eq

$Z_{1} e q=Z_{2} e q=Z_{S 1}+Z_{T 1}+Z_{1}$ saluran

transmisi.

Perhitungan $\mathrm{Z}_{0}$ eq :

$Z_{0} e q=Z_{T 0}+3 R_{N}+Z_{0}$ saluran

transmisi ....

Untuk gangguan hubung singkat satu phasa ketanah, dapat dilihat pada gambar dibawah ini :

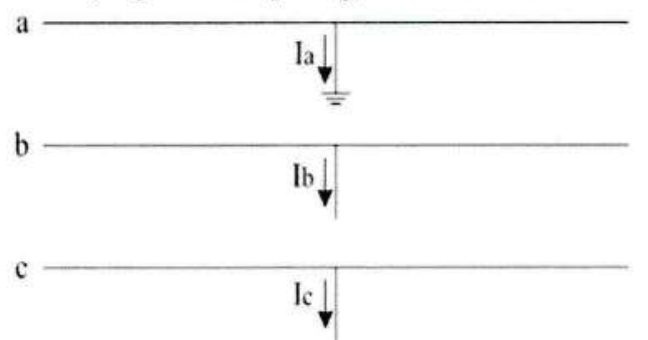

Gambar 8. Gangguan Hubung Singkat Satu Phasa Ketanah.

$I_{\text {satu phasa ketanah }}=\frac{3 \times V_{p h}}{Z_{1 e q}+Z_{2} e q+Z_{0 e q}}$
Rele jarak (distance relay) merupakan sistem proteksi yang paling utama pada saluran transmisi. Prinsip kerja rele jarak yaitu mengukur impedansi $(Z)$ transmisi dibagi menjadi beberapa daerah cakupan yaitu zona -1 , zona-2, zona-3, serta dilengkapi juga dengan teleproteksi (TP) agar proteksi bekerja selalu cepat dan seletif di dalam daerah pengamannya.

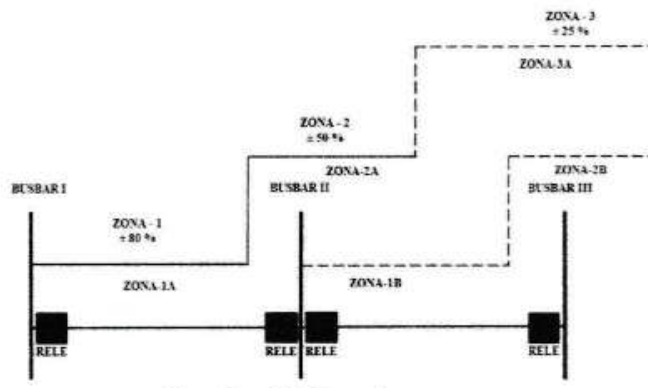

Gambar 9. Daerah pengaman rele jarak (distance relay).

Dalam perancangan dan analisa sebuah sistem tenaga listrik, sebuah software sangat dibutuhkan untuk merepresentasikan kondisi real sebelum sebuah sistem direalisasikan. Software ETAP (Electric Transient and Analysis Program) 12.6.0. merupakan salah satu software aplikasi yang digunakan untuk mensimulasikan sistem tenaga listrik. Software ETAP (Electric Transient and Analysis Program) 12.6.0. mampu bekerja dalam keadaan offline untuk simulasi tenaga listrik, dan online untuk pengelolaan data real-time atau digunakan untuk mengendalikan sistem secara real-time. Fitur yang terdapat di dalamnya pun bermacam-macam antara lain fitur yang digunakan untuk menganalisa pembangkitan tenaga listrik, sistem transmisi maupun sistem distribusi tenaga listrik.

Analisa sistem tenaga listrik yang dapat dilakukan Software ETAP (Electric Transient and Analysis Program)12.6.0. antara lain : analisa aliran daya, analisa hubung singkat, starting motor, koordinasi rele proteksi, analisa kestabilan transien, dan lain-lain. Dalam menganalisa sistem tenaga listrik, suatu diagram saluran tunggal (single line diagram) merupakan notasi yang disederhanakan untuk sebuah sistem tenaga listrik tiga phasa. Sebagai ganti dari representasi saluran tiga phasa yang terpisah, digunakanlah sebuah konduktor. 
Adapun diagram alir (flowchart) penelitian ini tersaji pada gambar 10 .

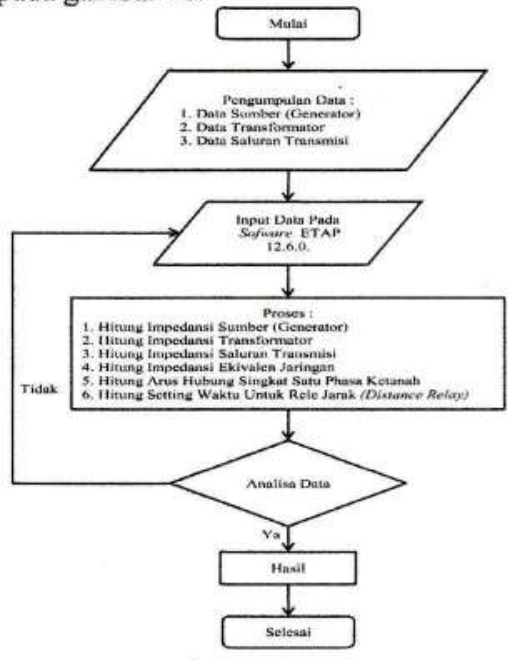

Gambar 10. Diagram Alir (flowchart).

\section{HASIL DAN PEMBAHASAN}

\section{Data Sumber (Generator)}

Tabel 1. Data Sumber (Generator) Pada Pembangkit Listrik Tenaga Air (PLTA) Poso Energy.

\begin{tabular}{|c|c|c|c|}
\hline \multirow{2}{*}{ Lokasi } & Generator & $\begin{array}{c}\text { Kapasitas } \\
\text { Daya } \\
(\mathbf{M N A})\end{array}$ & $\begin{array}{c}\text { Tegangan } \\
\text { Output } \\
(\mathbf{k V})\end{array}$ \\
\hline \multirow{2}{*}{$\begin{array}{c}\text { Pembangkit Listrik Tenaga } \\
\text { Air (PLTA) Poso Energy }\end{array}$} & \multirow{3}{*}{3} & 72,22 & 11 \\
\cline { 3 - 4 } & & 72,22 & 11 \\
\cline { 2 - 4 } & & 72,22 & 11 \\
\hline
\end{tabular}

Sumber : Pembangkit Listrik Tenaga Air (PLTA) Poso Energy.

\section{Data Transformator}

Tabel 2. Data Transformator Dari Beberapa c...........

\begin{tabular}{|c|c|c|c|c|c|c|}
\hline Lolus! & Trafo & 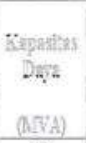 & $\begin{array}{l}\text { Tegangan } \\
\text { Operist } \\
\text { Rute: } \\
\text { Sekunder } \\
\text { (Ai) }\end{array}$ & 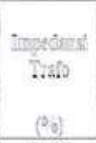 & Belitan & $\begin{array}{c}\text { Sisten } \\
\text { Pentanahan }\end{array}$ \\
\hline GI Pamolla & 1 & 10 & 15020 & 11,99 & $\mathrm{YNy} N 0$ & NGR \\
\hline GI Poso & 1 & 30 & $150 / 20$ & 12,48 & FNyNo & NGR \\
\hline GI Sidera & 1 & 30 & 15020 & 12.338 & MyNo & NGR \\
\hline \multirow{2}{*}{ G Tipo } & 1 & 30 & $150 / 20$ & 12,468 & INyNo & NGR \\
\hline & 1 & 60 & $150 / 22$ & 12,663 & KNy:NO & $\mathrm{NGR}$ \\
\hline
\end{tabular}

Data Saluran Transmisi

Tabel 3. Data Saluran Transmisi Yang Menghubungkan GI Pamona-GI Poso.

\begin{tabular}{|c|c|c|}
\hline \multicolumn{3}{|c|}{ Gardu Induk Panona-Gardu Induk Poso } \\
\hline Ilen & Uraian & Satuan \\
\hline Jenis Penghantar & $\operatorname{ACSR} 2 \times 240$ & 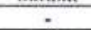 \\
\hline Kapasitas Pembawa Anus (CCC) & $2 \times 600$ & A \\
\hline Panjang Saluran & 43.45 & Kilometer \\
\hline Ratio CT & 8001 & - \\
\hline Ratio PI & $150.000 / 100$ & - \\
\hline Impedansi Unutan Positif $\left(Z_{1}\right)$ & $0,0592+j 0,1939$ & $\Omega / \mathrm{km}$ \\
\hline Impedansi Unutan Negatif $\left(Z_{2}\right)$ & $0,0592+J 0,1939$ & $\Omega / \mathrm{km}$ \\
\hline Impedansi Untan Nol (Z) & $0,155+J 0,3587$ & $\Omega / \mathrm{km}$ \\
\hline
\end{tabular}

Tabel 4. Data Saluran Transmisi Yang Menghubungkan GI Poso-GI Sidera.

\begin{tabular}{|c|c|c|}
\hline \multicolumn{3}{|c|}{ Gardu Induk Poso-Gardu Induk Sidera } \\
\hline Item & Uraian & Satuan \\
\hline Jenis Penghantar & $\operatorname{ACSR} 2 \times 240$ & - \\
\hline Kapasitas Pembawa Anus (CCC) & $2 \times 600$ & A \\
\hline Panjang Saluran & 141,6 & Kilometer \\
\hline Ratio CT & 8001 & $\cdot$ \\
\hline Ratio PT & $150.000 / 100$ & . \\
\hline Impedansi Urutan Positif $\left(Z_{1}\right)$ & $0.0592+\mathrm{J} 0.1939$ & $\Omega / \mathrm{km}$ \\
\hline Impedansi Urutan Negatif $\left(Z_{2}\right)$ & $0.0592+J 0.1939$ & $\Omega / \mathrm{km}$ \\
\hline Impedansi Unutan $\operatorname{Nol}\left(Z_{0}\right)$ & $0,155+\mathrm{J} 0,3587$ & $\Omega / \mathrm{km}$ \\
\hline
\end{tabular}

Sumber : Transmisi Dan Gardu Induk (Tragi) Palu.

Tabel 5. Data Saluran Transmisi Yang Menghubungkan GI Sidera-GI Tipo.

\begin{tabular}{|c|c|c|}
\hline \multicolumn{3}{|c|}{ Gardu Induk Sidera-Gardu Indnk Tipo } \\
\hline Item & Uraian & Satuan \\
\hline Jenis Penghantar & $\operatorname{ACSR} 1 \times 240$ & 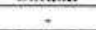 \\
\hline Kapasitas Pembawa Arus (CCC) & 600 & A \\
\hline Panjaug Saluran & 28,88 & Kilometer \\
\hline Ratio CT & 8001 & - \\
\hline Ratio PT & 150.000100 & - \\
\hline Impedansi Urutan Positif $\left(Z_{1}\right)$ & $0.118+\mathrm{J} 0.388$ & $\Omega / \mathrm{km}$ \\
\hline Impedansi Urutan Negatif $\left(Z_{2}\right)$ & $0.118+J 0.388$ & $\Omega / \mathrm{km}$ \\
\hline Impedansi Ururan $\mathrm{Nol}(\mathrm{Z})$ & $0.30+10.717$ & $\Omega / k m$ \\
\hline
\end{tabular}

Jenis Rele Yang Digunakan

Tabel 6. Data Jenis Rele Jarak (Distance Relay)Yang Digunakan Pada GI Pamona Dan GI Poso.

\begin{tabular}{|l|c|c|}
\hline \multirow{2}{*}{\multicolumn{1}{|c|}{ Rtem }} & \multicolumn{2}{|c|}{ Gardu Induk } \\
\cline { 2 - 3 } & Pamonan & Poso \\
\hline Merek & NARI & ABB \\
\hline Type & PCS902 & REL650 \\
\hline Proteksi & Poso & Sidera \\
\hline Karakteristik & Quadrilateral & Quadrilateral \\
\hline Pola Pengaman & PUTT & PUTT \\
\hline
\end{tabular}


Tabel 7. Data Jenis Rele Jarak (Distance Relay) Yang Digunakan Pada GI Poso Dan GI Sidera.

\begin{tabular}{|l|c|c|}
\hline \multicolumn{3}{|c|}{ Rele Jarak (Distance Relay) } \\
\hline \multirow{2}{*}{ Item } & \multicolumn{2}{c|}{ Gardu Induk } \\
\cline { 2 - 3 } & Poso & Sidera \\
\hline Merek & ABB & MICOM ALSTOM \\
\hline Type & REL650 & P443 \\
\hline Proteksi & Sidera & Tipo \\
\hline Karakteristik & Quadrilateral & Quadrilateral \\
\hline Pola Pengaman & PUTT & PUTT \\
\hline
\end{tabular}

Sumber : Transmisi Dan Gardu Induk (Tragi) Palu.

Tabel 8. Data Jenis Rele Jarak (Distance Relay) Yang Digunakan Pada GI Sidera Dan GI Tipo.

\begin{tabular}{|l|c|c|}
\hline \multicolumn{3}{|c|}{ Rele Jarak (Distance Relay) } \\
\hline \multirow{2}{*}{ Item } & \multicolumn{2}{c|}{ Gardu Induk } \\
\cline { 2 - 3 } & Sidera & Tipo \\
\hline Merek & MICOM ALSTOM & ABB \\
\hline Type & P443 & REL670 \\
\hline Proteksi & Tipo & Pasangkayu \\
\hline Karakteristik & Quadrilateral & Quadrilateral \\
\hline Pola Pengaman & PUTT & PUTT \\
\hline
\end{tabular}

Sumber : Transmisi Dan Gardu Induk (Tragi) Palu.

Perhitungan Arus dan Impedansi Gangguan Hubung Singkat Satu Phasa Ketanah

Perhitungan arus gangguan hubung singkat satu phasa ketanah pada saluran transmisi antara gardu induk sidera-gardu induk tipo dan persamaan yang digunakan adalah persamaan (12). Berikut perhitungan arus gangguan hubung singkat satu phasa ketanah pada saluran transmisi antara gardu induk sidera-gardu induk tipo:

Tabel 9. Hasil Analisa Perhitungan Arus Gangguan Hubung Singkat Satu Phasa Ketanah.

\begin{tabular}{|c|c|}
\hline \multirow{2}{*}{$\begin{array}{c}\text { Jarak } \\
\text { Gangguan } \\
\left({ }^{\circ} \text { o) }\right.\end{array}$} & $\begin{array}{c}\text { Arus Gangguan } \\
\text { Hubung Singkat } \\
\text { Satu Phasa Ketanah } \\
\text { (A) }\end{array}$ \\
\cline { 2 - 2 } & GI Sidera-GI Tipo \\
\hline 20 & 2069,50 \\
\hline 40 & 1989,56 \\
\hline 60 & 1909,38 \\
\hline 80 & 1830,63 \\
\hline 100 & 1753,98 \\
\hline
\end{tabular}

Tabel 10. Hasil Analisa Perhitungan Impedansi Gangguan Hubung Singkat Satu Phasa Ketanah

\begin{tabular}{|c|c|}
\hline $\begin{array}{c}\text { Jarak } \\
\text { Gangguan } \\
\left({ }^{\circ}\right)\end{array}$ & $\begin{array}{c}\text { Impedansi } \\
\text { Gangguan Satu } \\
\text { Phasa Ketanah } \\
(\Omega)\end{array}$ \\
\cline { 2 - 2 } & GI Sidera-GI Tipo \\
\hline 20 & 72,48 \\
\hline 40 & 75,39 \\
\hline 60 & 78,55 \\
\hline 80 & 81,93 \\
\hline 100 & 85,51 \\
\hline
\end{tabular}

Tabel 11. Hasil Analisa Perhitungan Nilai Setting Rele Jarak (Distance Relay.

\begin{tabular}{|c|c|c|c|c|c|c|}
\hline \multirow{2}{*}{ Lokasi Setting } & \multicolumn{2}{|c|}{ Zona $1(\Omega)$} & \multicolumn{2}{|c|}{ Zona $2(\Omega)$} & \multicolumn{2}{|c|}{ Zona $3(\Omega)$} \\
\hline & $\mathrm{Zl}_{\mathrm{t}}$ & $\mathrm{Z1}_{\mathrm{B}}$ & $\mathrm{Z2}_{\mathrm{A}}$ & $\mathrm{Z}_{2_{\mathrm{B}}}$ & 23.1 & $\mathrm{Z3}_{4}$ \\
\hline GI Sidera - GI Tipo & 17,566 & 33,836 & 31,618 & 60,904 & . & $\cdot$ \\
\hline Waktu Setting (s) & \multicolumn{2}{|c|}{0} & \multicolumn{2}{|c|}{0,4} & \multicolumn{2}{|c|}{0.8} \\
\hline
\end{tabular}

Perhitungan Gangguan Hubung Singkat (Short Circuit Fault) dan Setting Rele Jarak (Distance Relay) Pada Saluran Udara Tegangan Tinggi (SUTT) Antara Gardu Induk Sidera - Gardu Induk Tipo Menggunakan Software ETAP (Electric Transient and Analysis Program) 12.6.0.

Untuk menghitung arus gangguan hubung singkat (short circuit fault) pada saluran udara tegangan tinggi (SUTT) $150 \mathrm{kV}$ antara gardu induk sidera-gardu induk tipo yaitu membuat single line diagram dari pusat pembangkit sampai ke gardu induk tipo seperti dibawah ini :

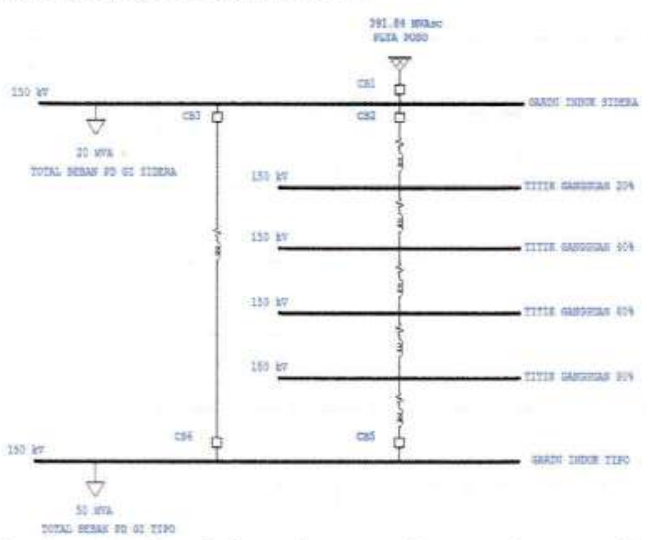

Gambar 11. Single line diagram sistem sulteng pada Software ETAP (Electric Transient and Analysis Program) 12.6.0.

\section{Short Circuit Study Case}

Short Circuit Study Case (SCSC) menganalisa gangguan hubung singkat tiga phasa, satu phasa ke tanah, antar phasa dan dua phasa ke tanah pada sistem tenaga listrik. Program Short-Circuit dibuat 
Pada Software ETAP (Electric Transient and Analysis Program) 12.6.0. menggunakan standar ANSI/IEEE (seri C37) dan IEC (IEC 909 dan lainnya) dalam menganalisa gangguan hubung singkat yang bisa dipilih sesuai dengan keperluan. Untuk memulai short-circuit Analisis maka single line diagram (SLD) sistem tenaga listrik digambarkan terlebih dahulu dengan memperhatikan data yang akan diinput seperti pada gambar dibawah ini :

Metode arus gangguan hubung singkat : isi sesuai dengan data sesuai dengan petunjuk gambar dibawah ini. Klik info kemudian isi data sesuai dengan data yang ada.

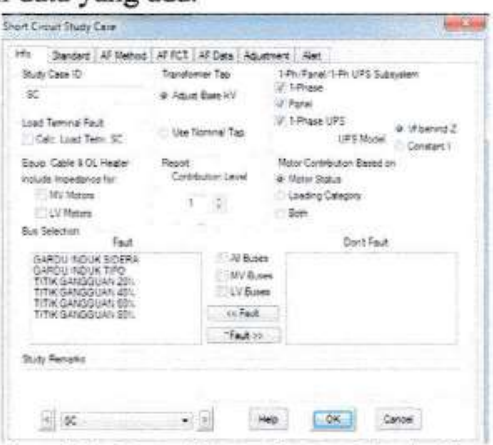

Gambar 12. Data Short Circuit Study Case Pada Software ETAP (Electric Transient and Analysis Program) 12.6.0.

Selanjutnya klik standard kemudian isi data sesuai dengan data yang ada.

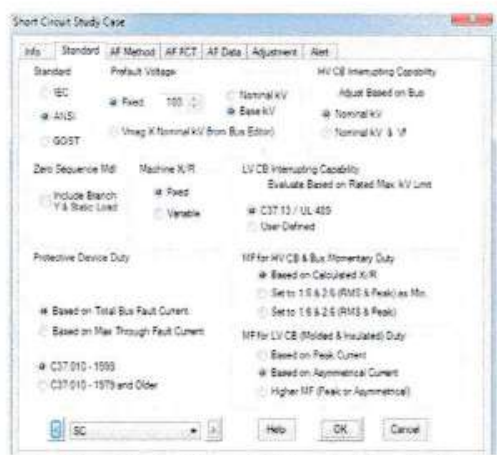

Gambar 13. Data Short Circuit Study Case Pada Software ETAP (Electric Transient and Analysis Program) 12.6.0.
Hasil Simulasi Menggunakan Software ETAP (Electric Transient and Analysis Program) 12.6.0.

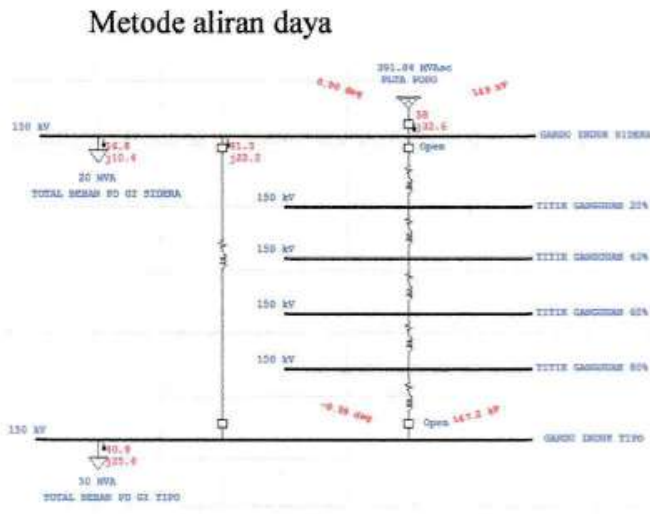

Gambar 14. Hasil Simulasi Load Flow Study Case Pada Software ETAP (Electric Transient and Analysis Program) 12.6.0.

Metode arus gangguan hubung singkat

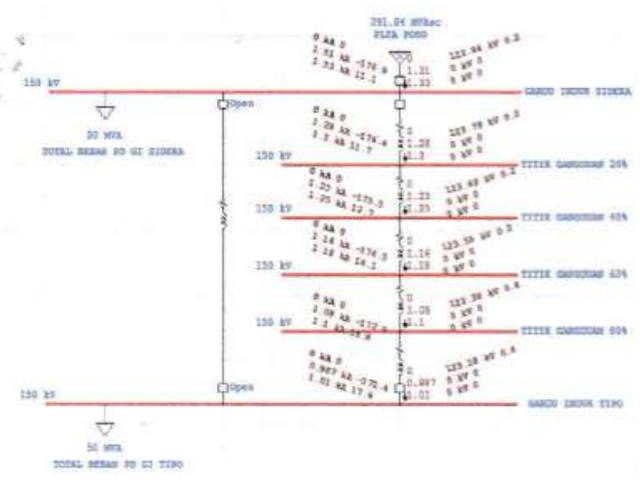

Gambar 15. Hasil Simulasi Load Flow Study Case Pada Software ETAP (Electric Transient and Analysis Program) 12.6.0.

\section{Analisa Gangguan Hubung Singkat}

Pada gardu induk sidera-gardu induk tipo, terlihat arus hubung singkat terbesar terjadi pada jenis gangguan hubung singkat satu phasa ketanah dengan jarak gangguan $20 \%$ dari panjang saluran sebesar 2069,50 A dan terlihat arus hubung singkat terkecil terjadi pada jenis gangguan hubung singkat satu phasa ketanah dengan jarak gangguan $100 \%$ dari panjang saluran sebesar $1753,98 \mathrm{~A}$. Berikut grafik perbandingan arus gangguan terhadap titik lokasi gangguan : 


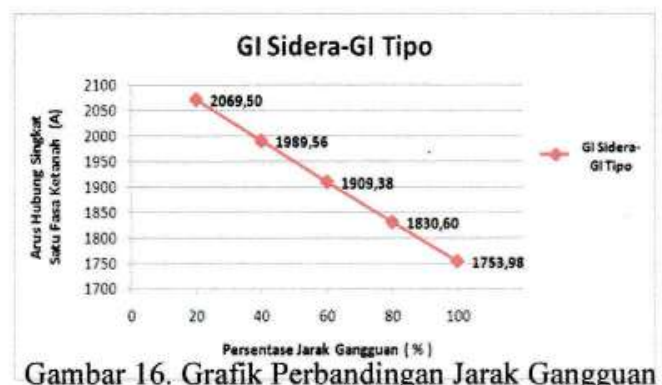

Terhadap Arus Gangguan Satu Phasa Ketanah.

Analisa Setting Rele Jarak (Distance Relay) Berdasarkan Perhitungan Gangguan Hubung Singkat.

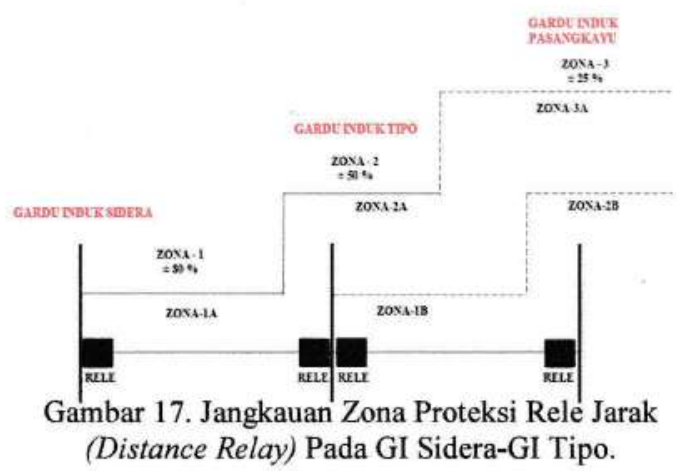

Berdasarkan hasil perhitungan gangguan hubung singkat, setting rele jarak(distance relay) pada gardu induk sidera-gardu induk tipo, dapat dilihat pada tabel 10 .

Tabel 12. Hasil Perbandingan $Z_{\text {setting }}$ dengan $Z_{\text {gangguan }}$ Pada GI Sidera-GI Tipo.

\begin{tabular}{|c|c|c|c|c|c|}
\hline \multicolumn{6}{|c|}{ Gardu Induk Sidera-Gardu Induk Tipo } \\
\hline $\begin{array}{c}\text { Lokasi } \\
\text { Gangguan } \\
\left({ }^{\circ} 0\right)\end{array}$ & $\begin{array}{c}\text { Jenis } \\
\text { Gangguan }\end{array}$ & $\begin{array}{l}\mathrm{Z}_{\mathrm{f}} \\
(\mathrm{Q})\end{array}$ & $\begin{array}{c}Z_{\text {Settipg }} \\
(\Omega)\end{array}$ & Ket. & $\begin{array}{c}\text { Zone } \\
\text { Operate }\end{array}$ \\
\hline 20 & $\begin{array}{l}\text { Satu Phasa } \\
\text { Ke Tanah }\end{array}$ & 72,48 & 93,56 & Operate & Zona- $I_{A}$ \\
\hline 40 & $\begin{array}{l}\text { Satu Phasa } \\
\text { Ke Tanah }\end{array}$ & 75,39 & 93,56 & Operate & Zona- $I_{A}$ \\
\hline 60 & $\begin{array}{l}\text { Satu Phasa } \\
\text { Ke Tanah }\end{array}$ & 78,55 & 93,56 & Operate & Zona- $1_{A}$ \\
\hline 80 & $\begin{array}{l}\text { Satu Phasa } \\
\text { Ke Tanah }\end{array}$ & 81,93 & 93,56 & Operate & Zona- $I_{A}$ \\
\hline 100 & $\begin{array}{l}\text { Satu Phasa } \\
\text { Ke Tanah }\end{array}$ & 85,51 & 114,04 & Operate & Zona- $2_{\mathrm{A}}$ \\
\hline
\end{tabular}

Perbandingan Hasil Perhitungan Setting Rele Jarak (Distance Relay) Dengan Data Dilapangan.

Tabel 13. Perbandingan Hasil Perhitungan Setting Rele Jarak (Distance Relay)Dengan Data Dilapangan.

\begin{tabular}{|c|c|c|c|c|c|}
\hline \multirow[t]{2}{*}{ Lokasi Setting } & \multirow[t]{2}{*}{$\begin{array}{c}\text { Zona } \\
\text { Proteksi }\end{array}$} & \multicolumn{2}{|c|}{$\begin{array}{c}\text { Data Hasil } \\
\text { Perhitungan } \\
(0)\end{array}$} & \multicolumn{2}{|c|}{$\begin{array}{c}\text { Data Terpasang } \\
\text { di Lapangan } \\
(2) \\
\end{array}$} \\
\hline & & $\mathrm{Z}_{\cdot \mathrm{A}}$ & $Z_{-B}$ & $\mathrm{Z} \cdot \mathrm{A}_{\mathrm{A}}$ & $Z_{\cdot B}$ \\
\hline \multirow{3}{*}{ GI Sidera-GI Tipo } & Zona 1 & 17,566 & 33,836 & 19,356 & 45,440 \\
\hline & Zona 2 & 31,618 & 60,904 & 43,056 & 62.069 \\
\hline & Zona 3 & . & $\cdot$ & - & . \\
\hline
\end{tabular}

Perbandingan Hasil Perhitungan Setting Rele Jarak (Distance Relay) Dengan Data PT. PLN. Wilayah Suluttenggo AP2B Sistem Minahasa dan Software ETAP (Electric Transient and Analysis Program) 12.6.0.

Tabel 14. Perbandingan Hasil Perhitungan Manual Dengan Data PT. PLN. Wilayah Suluttenggo AP2B Sistem Minahasa dan Software ETAP (Electric Transient and Analysis Program)12.6.0.

\begin{tabular}{|c|c|c|c|}
\hline \multirow[t]{2}{*}{$\begin{array}{l}\text { Jarak } \\
\text { Gangguan } \\
(\%)\end{array}$} & $\begin{array}{l}\text { Arus Gangguan } \\
\text { Hubung Singkat } \\
\text { Satu Phasa } \\
\text { Ketanah } \\
\text { (A) }\end{array}$ & $\begin{array}{c}\text { Arus Gangguan } \\
\text { Hubung Singkat } \\
\text { Satu Phasa } \\
\text { Ketanah } \\
\text { (A) } \\
\text { (Data PT.PL.N) }\end{array}$ & $\begin{array}{c}\text { Arus Gangguan } \\
\text { Hubung Singkat } \\
\text { Satu Phasa } \\
\text { Ketanah } \\
\text { (A) } \\
\text { (Data ETAP) }\end{array}$ \\
\hline & GI Sidera-GI Tipo & GI Sidera-GI Tipo & GI Sidera-GI Tipo \\
\hline 20 & 2069,50 & 1629,52 & 1630 \\
\hline 40 & 1989,56 & 1605,58 & 1610 \\
\hline 60 & 1909,38 & 1579,55 & 1580 \\
\hline 80 & 1830,63 & 1540,65 & 1550 \\
\hline 100 & 1753,98 & 1510 & 1510 \\
\hline
\end{tabular}

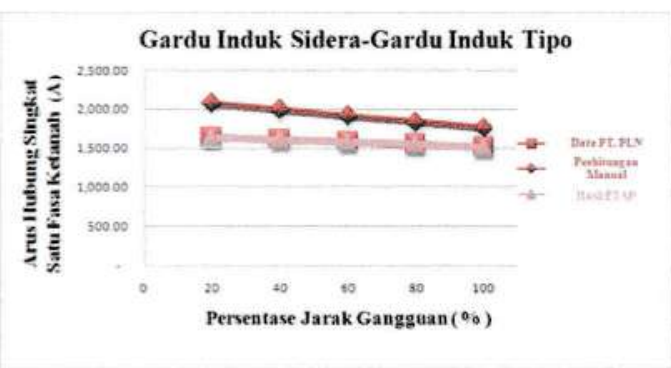

Gambar 18. Grafik Perbandingan Hasil Perhitungan Manual Dengan Data PT. PLN. Wilayah Suluttenggo AP2B Sistem Minahasa dan Software ETAP (Electric Transient and Analysis Program) 12.6.0.

Pada gambar 18. menunjukkan perbandingan hasil perhitungan manual nilai arus gangguan hubung singkat satu phasa ketanah dengan data PT. PLN. Wilayah Suluttenggo AP2B Sistem Minahasa dan 
hasil simulasi Software ETAP (Electric Transient and Analysis Program)12.6.0. Jika dilihat dari hasil perhitungan manual nilai arus gangguan hubung singkat satu phasa ketanah dengan data PT. PLN. Wilayah Suluttenggo AP2B Sistem Minahasa dan hasil simulasi Software ETAP (Electric Transient and Analysis Program)12.6.0., perhitungan manual lebih besar dari pada data yang dimiliki oleh PT. PLN. Wilayah Suluttenggo AP2B Sistem Minahasa dan hasil simulasi Software ETAP (Electric Transient and Analysis Program)12.6.0., karena kami mengabaikan nilai rugi-rugi saluran transmisi dimana nilai yang dimiliki rugi-rugi PT. PLN. Wilayah Suluttenggo AP2B Sistem Minahasa yaitu 2\%-3\%.

\section{KESMIPULAN DAN SARAN}

Arus gangguan hubung singkat terbesar terjadi pada jenis gangguan hubung singkat satu phasa ketanah dengan jarak lokasi gangguan $20 \%$ sebesar $2069,50 \mathrm{~A}$, dan arus gangguan hubung singkat terkecil terjadi pada jenis gangguan hubung singkat satu phasa ketanah dengan jarak lokasi gangguan $100 \%$ sebesar $1753,98 \mathrm{~A}$. Hal ini sesuai dengan teori yang ada, bahwa jarak berpengaruh terhadap gangguan hubung singkat, baik gangguan satu phasa ketanah, dan dengan adanya perhitungan hasil setting rele jarak (distance relay), maka untuk zona 1 nilai $Z_{\text {Setting-1 }}$ yaitu $17,566 \Omega$ dan nilai $Z_{\text {Setting-0 }}$ yaitu 33,836 $\Omega$, sedangkan untuk zona 2 nilai $Z_{\text {Setting-1 }}$ yaitu 31,618 $\Omega$ dan nilai $Z_{\text {Setting- } 0}$ yaitu $60,904 \Omega$.

\section{DAFTAR PUSTAKA}

[1] Adrianus Tendeng dan Yulius, S.P., 1995, "Evaluasi Sistem Proteksi Jaringan Tegangan $150 \mathrm{KV}$ Tello-Bakaru”, Program Teknik Tenaga Listrik, Fakultas Teknik, Jurusan Elektro Teknik, Universitas Hasanuddin, Ujung Pandang.

[2] B.Ravindranath dan M. Chander., 1997, "Power System Protection and Switchgear".

[3] C.Russell Mason., 1956, "The Art and Science of Protective Relaying".

[4] Junaptha, Adrianto. S., 2015, "Analisis Gangguan Hubung Singkat Untuk Setting Distance Relay Pada SUTT 150 KV Antara GI Pamona-GI Sidera",Jurusan Teknik Elektro, Fakultas Teknik, Universitas Tadulako, Palu.

[5] Nopransi, S., 2011, "Koordinasi Setting Relay Jarak pada Transmisi 150 KV PLTU 2 SULUT $2 x 25 M W^{\prime \prime}$, Jurusan Teknik Elektro-FT, Universitas Samratulangi, Manado.

[6] PT. PLN (persero) Pusat Pendidikan dan Pelatihan "Monitoring Peralatan Gardu Induk dan Sistem Pelapora, Halaman 285-329.
[7] Stevenson, William D., 1996, "Analisis Sistem Tenaga Listrik",Edisi 4, Terjemahan Kamal Idris, Jakarta : Erlangga.

[8] Tanzil, R.A., 2011, "Scanning Dan Resetting Distance Relay Pada Penghantar $150 \mathrm{KV}$ Kudus Arah Jekulo", Media Elektrika, Jurusan Teknik Elektro, Universitas Muhammadiyah Semarang, Vol. 4 No.2. 